\title{
Recent updates of genetic and genomic alterations in hepatocellular carcinoma
}

\section{Zhang Zhao, Jian Huang}

Liver Research Center, Experimental Center, Beijing Friendship Hospital, Capital Medical University, Beijing 100050, China

\begin{abstract}
Hepatocellular carcinoma $(\mathrm{HCC})$ is one of the most common malignant cancers worldwide. However, the molecular mechanisms underlining the development and progression of HCC remain unclear. Genetic and genomic alterations are common events in various types of cancers including HCC. With the development and application of next generation sequencing technology, novel genetic and genomic alterations in $\mathrm{HCC}$ have been identified. Here, the article reviews recent updates on the genetic and genomic alterations in HCC.
\end{abstract}

Key words: Hepatocellular carcinoma; genetics; genomics; next generation sequencing

\section{Address for correspondence:}

Prof. Jian Huang, Liver Research Center, Beijing Friendship Hospital, Capital Medical University, 95 Yong An Road, Beijing 100050 , China. E-mail: huangj1966@hotmail.com

Received: 05-07-2015, Accepted: 01-10-2015

\section{INTRODUCTION}

Hepatocellular carcinoma (HCC) is one of the most common malignant neoplasms worldwide, with a prevalence of more than $50 \%$ in China. Hepatitis $B$ virus (HBV) or hepatitis $\mathrm{C}$ virus (HCV) infection, ingestion of food contaminated with aflatoxin B1, and alcohol consumption are considered major risk factors for HCC development. ${ }^{[1]}$ Despite wellestablished risk factors, the specific molecular mechanisms underlining pathogenesis of HCC remain unclear. Genetic and genomic alterations are common events in various types of cancers including HCC, and may be associated with the development and progression of cancer. With the development of the technology of next generation sequencing, that is, whole-genome sequencing, novel genetic and genomic alterations have been identified. Recent studies on whole-genome sequencing of

\begin{tabular}{|l|c|}
\hline \multicolumn{3}{|c|}{ Access this article online } \\
\hline \multirow{2}{*}{ Website: } & Quick Response Code \\
http://www.hrjournal.net/ & \\
\hline & DOI: \\
10.4103/2394-5079.168446 & \\
\end{tabular}

HCC confirmed the important roles of previously reported genetic and genomic alterations in the development and progression of HCC. ${ }^{[2]}$ However, the fact that the most frequently mutated genes were generally previously reported, and that few novel mutated genes with high frequency were identified by the whole-genome sequencing suggests the complexity regarding the role of genetic mutations in the pathogenesis of HCC. In this paper, we review recent updates on genetic mutations and genomic imbalances in HCC.

\section{GENETIC ALTERATIONS: MUTATION AND SINGLE NUCLEOTIDE POLYMORPHISM}

\section{Somatic mutation}

Previous studies have demonstrated that the most significantly mutated genes in HCC include tumor

This is an open access article distributed under the terms of the Creative Commons Attribution-NonCommercial-ShareAlike 3.0 License, which allows others to remix, tweak, and build upon the work non-commercially, as long as the author is credited and the new creations are licensed under the identical terms.

\section{For reprints contact: service@oaepublish.com}

How to cite this article: Zhao Z, Huang J. Recent updates of genetic and genomic alterations in hepatocellular carcinoma. Hepatoma Res $2016 ; 2: 31-5$. 
protein p53 (TP53), catenin (cadherin-associated protein) beta 1 ( $\beta$-catenin, CTNNB1), and AT-rich interactive domain-containing protein 2 (ARID2), with mutation frequency over $15 \% .{ }^{[2-4]}$ Other mutated genes such as SMAD2/SMAD4 in the transforming growth factor beta (TGF- $\beta$ ) pathway, caspase 8 (CASP8), and Kruppel-like factor 6 were identified with mutation frequency around $10 \%$ in $\mathrm{HCC},{ }^{[5-7]}$ while most other mutated genes were identified with relatively low frequency of $<10 \%$ in HCC. ${ }^{[2]}$ Germline mutations in the TP53 gene have been identified in patients with Li-Fraumeni syndrome, which is an inherited cancer predisposition syndrome characterized by a wide spectrum of neoplasms. ${ }^{[8]}$ Somatic TP53 mutations were identified in virtually any tumor type including HCC, particularly following exposure to aflatoxin. ${ }^{[9,10]}$ According to the IARC database, 1840 TP53 somatic mutations have been identified in $31.19 \%$ of liver cancer cases (IARC TP53 Database R17, http://p53.iarc.fr/). The mutation of $\beta$-catenin gene in WNT/CTNNB1 pathway has been identified in HCC with a frequency of $15.9 \%$, which can lead to the activation of CTNNB1 gene with the consequence of overexpression and accumulation of $\beta$-catenin..$^{[3]}$ ARID2 is a subunit of the PBAF chromatin-remodeling complex, which facilitates ligand-dependent transcriptional activation by nuclear receptors. In the United States and Europe, 18.2\% of HCV-associated HCC cases were identified with ARID2-inactivating mutations. ${ }^{[4]}$ However, studies have also reported mutation frequencies of approximately $5-10 \%$ for ARID2 in HCC and truncation of ARID2 leads to loss of protein function and chromatin dysregulation..$^{[4,11,12]}$

With the development of whole-genome sequencing technology, the next generation sequencing of genome DNA provides the possibility that more novel genetic and genomic alterations may be discovered and may provide new insights for understanding the pathogenesis of HCC. However, several recent studies using next generation sequencing for analysis of mutation in HCC showed that the most frequent mutations with mutated rate over $10 \%$ were mainly genes reported previously such as TP53, $\beta$-catenin, and genes of chromatin-remodeling complex such as AT-rich interactive domain 1A (ARID1A) $(14 / 110) \cdot{ }^{[2,13,14]}$ Only a few genes were identified with mutation rates over $10 \%$, for example, the lowdensity lipoprotein receptor-related protein 1B gene, reported by Kan et al..$^{[2]}$ to have a mutation rate of $11.4 \%$ in patients with family hypercholesterolemia. Notably, several components of the chromatinremodeling complex, such as ARID1A and ARID2 were mutated in over $10 \%$ HCC specimens, ${ }^{[13,14]}$ similar to previous reports, confirming the important role of chromatin-remodeling in the pathogenesis of HCC. In addition, Janus kinase 1 (JAK1) mutation was identified with mutation rate of $9.1 \%$ through the whole-genome sequencing of 88 HCC cases, and the JAK/STAT pathways were altered in $45.5 \%$ of cases, ${ }^{[2]}$ inconsistent with a previous study which reported low frequency $(1 / 84,1.2 \%)$ of JAK1 mutation in HCC ${ }^{[15]}$ implying that the JAK/STAT pathways may act as major oncogenic drivers in HCC. However, the fact that the most frequently mutated genes were generally previously reported, and that few novel mutated genes with high mutation frequencies were identified by whole-genome sequencing suggests the complexity regarding the role of genetic mutations in the pathogenesis of HCC.

It has been reported that genomic instability is a characteristic of most cancers. Genomic instability results from mutations in DNA repair genes and drives cancer development in hereditary cancers. However, in sporadic cancers, previous studies and recent high-throughput sequencing studies suggested that mutations in DNA repair genes were infrequent. Instead, the mutation patterns of the tumor suppressor TP53, ataxia telangiectasia mutated $(A T M)$, and cyclin-dependent kinase inhibitor 2A (CDKN2A) support the oncogene-induced DNA replication stress model, which attributes genomic instability and TP53 and ATM mutations to oncogene-induced DNA damage, that is, high frequency of TP53 mutations in human cancers could be in response to oncogene-induced DNA damage. ${ }^{[16]}$ The hypothesis was confirmed by several studies showing that deletion of the TP53 gene in mouse models and human cells did not lead to aneuploidy, and that in human precancerous lesions, genomic instability was present before the establishment of TP53 mutations. ${ }^{[17-19]}$ Consistent with the above studies, previous studies and recent whole-genome sequencing of HCC also showed that mutations in DNA repair genes in HCC were infrequent,,$[2,13,14,20]$ suggesting there may be similar mechanisms of genetic mutations in somatic HCC, that is, high frequency of TP53 mutations and additional genetic mutations favoring cancer development in somatic HCC could be in response to oncogene-induced DNA damage.

\section{Single nucleotide polymorphism}

Single nucleotide polymorphism (SNP) is the most common genetic variation in the human genome. 
Genome-wide association study (GWAS) was also applied for SNP analysis of HCC in recent years. In a GWAS of HCC in Japanese population, one intronic SNP (rs1012068) in the DEP domain containing 5 gene was identified to be associated with HCC risk. ${ }^{[21]}$ In a GWAS of HCC in chronic HBV carriers of Chinese ancestry, one intronic SNP (rs17401966) in kinesin family member $1 \mathrm{~B}$ was identified to be highly associated with HBV-related HCC. ${ }^{[22]}$ In addition, SNP (rs9679162) in polypeptide $\mathrm{N}$-acetylgalactosaminyl transferase 14 (GALNT14) have been shown to be associated with chemotherapy response in patients with advanced HCC; for advanced HCC patients treated with FMP (fluorouracil oxantrone cisplatin) chemotherapy, GALNT14 genotype (rs9679162) was an effective predictor of the therapeutic outcome. ${ }^{[23,24]}$

\section{GENOMIC ALTERATION: GENOMIC IMBALANCES}

\section{Copy number variation-genomic gain or loss}

Chromosomal abnormalities in HCC have been well reported, and comparative genomic hybridization (CGH) has revealed a consistent pattern of genomic gains and losses involved in the development and progression of HCC. The most prominent changes are partial or entire gains of chromosome arms 1q, $8 \mathrm{q}$, and $2 \mathrm{q}$; and losses of 1, 4q, 8p, 13q, 16q, and $17 \mathrm{p}$. In one meta-analysis, using conventional $\mathrm{CGH}$ analysis with low resolution (approximately $2 \mathrm{Mb}$ ) from several studies, it was revealed that the most prominent changes were gains of $1 \mathrm{q}(57.1 \%), 8 \mathrm{q}$ (46.6\%), $6 \mathrm{p}(23.3 \%)$, and $17 \mathrm{q}(22.2 \%)$; and losses of 8p (38\%), 16q (35.9\%), 4q (34.3\%), 17p (32.1\%), and $13 q(26.2 \%){ }^{[25]}$ Using array CGH analysis from four studies, it was revealed that loci with genomic gains with a prevalence of more than $25 \%$ included $1 \mathrm{q}, 6 \mathrm{p}$, 8q, 17q, 20p, 5p15.33, and 9q34.2-34.3; and loci with genomic losses with prevalence of more than $25 \%$ comprised 4q, 6q, 8p, 9p, 13q, 14q, 16q, and $17 \mathrm{p}$; and were associated with 31 classical molecular pathways, particularly the antivirus immunological pathway. ${ }^{[25]}$ A series of tumor suppressor genes have been identified in these regions, such as PR domain containing 5 (PRDM5, 4q26), TP53 (17p13.1), retinoblastoma $1(R B 1,13 q 14)$, and cadherin 1 , type 1 (CDH1, 16q22.1). ${ }^{[26-28]}$ Some clinicopathological associations have been noted with specific abnormalities: Losses of $4 \mathrm{q}, 13 \mathrm{q}$, and $16 \mathrm{q}$ are associated with HBV infection, ${ }^{[25]}$ loss of $4 \mathrm{q}$ has been associated with elevated $\alpha$-fetoprotein levels, TP53 mutations, ${ }^{[29]}$ tumor size, and vascular invasion ${ }^{[30]}$ while $9 p$ and $6 q$ losses have been reported to be independent predictors of poor outcome of HCC patients, ${ }^{[31]}$ and that losses of $4 \mathrm{q}, 13 \mathrm{q}$, and $16 \mathrm{q}$ are associated with $\mathrm{HBV}$ infection.

Similar to the finding reported by the previous array CGH based study, a recent whole-genome sequencing study on HCC showed similar patterns of genomic imbalances: The copy number variation in HCC genomes is dominated by large-scale amplifications and deletions of chromosomal arms or entire chromosomes including gain at 1q, 5p, $6 \mathrm{p}$, $8 \mathrm{q}, 17 \mathrm{q}$, and $20 \mathrm{q}$; and deletion at Xq or loss at $4 \mathrm{p} / 4 \mathrm{q}$, $8 \mathrm{p}, 13 \mathrm{p} / 13 \mathrm{q}, 16 \mathrm{p} / 16 \mathrm{q}, 17 \mathrm{p}, 21 \mathrm{p} / 21 \mathrm{q}$, and $22 \mathrm{q} \cdot{ }^{[2]}$

\section{Loss of heterozygosity}

Loss of heterozygosity ( $\mathrm{LOH}$ ) refers to one of two polymorphic alleles on a tumor chromosome. Zhang et al..$^{[32]}$ identified a high frequency of $\mathrm{LOH}$ $4 \mathrm{q}(48.1 \%)$ in HCC, in which the caspase- 6 and rasrelated $\mathrm{C} 3$ botulinum toxin substrate 1 pseudogene 5 in the region 4q24-26 may be related with tumor growth. Additionally, inhibitor of growth family, member 2 (ING2) in the region $4 \mathrm{q} 34.3-4 \mathrm{q} 35$ was found to be down-regulated frequently in HCC, and its gene expression was also significantly decreased, suggesting that ING2 might be a tumor-specific glycoprotein of HCC. ${ }^{[32]}$ In a variety of human tumors, the most common chromosomal changes were $8 p$ allelic loss, suggesting that there might be one or several tumor suppressor genes on the short arm of chromosome 8. LOH was frequently observed on chromosomes 8p22-23, but the gene closely related with HCC was still unknown. However, Peng et al. ${ }^{[33]}$ identified that $\mathrm{LOH}$ of zinc finger, DHHCtype containing 2 (in 8p22-23 was associated with early metastatic recurrence of HCC after liver transplantation.

\section{Gene amplification and deletion}

Gene amplification in certain regions of chromosomes plays a crucial role in the development and progression of human malignancies. Recently, researchers found amplification of the ecotropic viral integration site 1 (EVI1) gene at the chromosomal region 3q26 in the HCC cell line JHH-1..$^{[34]}$ A copy number gain of EVI1 was observed in $36 \%(24 / 66)$ of primary HCC tumors. EVI1 antagonizes TGF- $\beta$-mediated growth inhibition in HCC cells, suggesting the EVI1 may be a potential molecular target for the development of novel therapies to treat HCC. ${ }^{[34]}$ In another study, granulin-epithelin precursor, a secretory growth factor, was identified with gene amplification in $20 \%$ of HCC cases, and this amplification was correlated with enhanced expression levels in the same HCC 
cases. ${ }^{[35]}$ Human epithelial growth factor receptor-2 (HER2) and topoisomerase II alpha (TOP2A) have been identified to be co-amplified in breast and some other cancers, ${ }^{[36]}$ but the HER2 gene status and HER2 protein expression in HCC has been controversial. ${ }^{[37]}$ However, no correlation was shown between TOP2A amplification and TOP2A overexpression in HCC. ${ }^{[38]}$

Gene deletion of tumor suppressor genes in certain regions of chromosomes also plays a crucial role in the pathogenesis of cancer. CDKN2A is a tumor suppressor gene that encodes for $\mathrm{p} 16$ and p14ARF. In a recent whole-genome sequencing study, CDKN2A deletion was identified in $10.2 \%$ HCC cases. ${ }^{[2]}$ Protein tyrosine phosphatase, receptor type $\mathrm{D}$, a tumor suppressor gene, which was previously identified to be frequently deleted in several cancers, ${ }^{[39-41]}$ was also identified with homozygous deletion in human HCCs. ${ }^{[42]}$

\section{PROSPECTS}

In summary, multiple lines of evidence have shown that the genetic and genomic alterations play important roles in the development and progression of HCC. The next generation sequencing of genomic DNA provides the possibility that more novel genetic and genomic alterations may be discovered and may provide new insights for understanding of the pathogenesis of HCC. However, further studies on the role of genetic mutation and genomic imbalances in the pathogenesis of HCC, as well as related functional and mechanistic studies are also urgently needed.

\section{Financial support and sponsorship}

This work is supported by a grant from the Beijing Natural Science Foundation (7132058).

\section{Conflicts of interest}

There are no conflicts of interest.

\section{REFERENCES}

1. Theise ND, Chen CJ, Kew MC. Liver cancer. In: Stewart B, Wild C, editors. World Cancer Report 2014. Lyon: International Agency for Research on Cancer; 2014. p. 577-93.

2. Kan Z, Zheng H, Liu X, Li S, Barber TD, Gong Z, Gao H, Hao K, Willard MD, Xu J, Hauptschein R, Rejto PA, Fernandez J, Wang G, Zhang Q, Wang B, Chen R, Wang J, Lee NP, Zhou W, Lin Z, Peng Z, Yi K, Chen S, Li L, Fan X, Yang J, Ye R, Ju J, Wang K, Estrella H, Deng S, Wei P, Qiu M, Wulur IH, Liu J, Ehsani ME, Zhang C, Loboda A, Sung WK, Aggarwal A, Poon RT, Fan ST, Wang J, Hardwick J, Reinhard C, Dai H, Li Y, Luk JM, Mao M. Wholegenome sequencing identifies recurrent mutations in hepatocellular carcinoma. Genome Res 2013;23:1422-33.

3. Miyoshi Y, Iwao K, Nagasawa Y, Aihara T, Sasaki Y, Imaoka S, Murata M, Shimano T, Nakamura Y. Activation of the beta-catenin gene in primary hepatocellular carcinomas by somatic alterations involving exon 3. Cancer Res 1998;58:2524-7.

4. Li M, Zhao H, Zhang X, Wood LD, Anders RA, Choti MA, Pawlik TM, Daniel HD, Kannangai R, Offerhaus GJ, Velculescu VE, Wang L, Zhou S, Vogelstein B, Hruban RH, Papadopoulos N, Cai J, Torbenson MS, Kinzler KW. Inactivating mutations of the chromatin remodeling gene ARID2 in hepatocellular carcinoma. Nat Genet 2011;43:828-9.

5. Yakicier MC, Irmak MB, Romano A, Kew M, Ozturk M. Smad2 and Smad4 gene mutations in hepatocellular carcinoma. Oncogene 1999; 18:4879-83.

6. Soung YH, Lee JW, Kim SY, Sung YJ, Park WS, Nam SW, Kim SH, Lee JY, Yoo NJ, Lee SH. Caspase- 8 gene is frequently inactivated by the frameshift somatic mutation 1225_1226delTG in hepatocellular carcinomas. Oncogene 2005;24:141-7.

7. Kremer-Tal S, Reeves HL, Narla G, Thung SN, Schwartz M, Difeo A, Katz A, Bruix J, Bioulac-Sage P, Martignetti JA, Friedman SL. Frequent inactivation of the tumor suppressor Kruppel-like factor 6 (KLF6) in hepatocellular carcinoma. Hepatology 2004;40:1047-52.

8. Malkin D, Li FP, Strong LC, Fraumeni JF Jr, Nelson CE, Kim DH, Kassel J, Gryka MA, Bischoff FZ, Tainsky MA, Friend SH. Germ line p53 mutations in a familial syndrome of breast cancer, sarcomas, and other neoplasms. Science 1990;250:1233-8.

9. Hussain SP, Schwank J, Staib F, Wang XW, Harris CC. TP53 mutations and hepatocellular carcinoma: insights into the etiology and pathogenesis of liver cancer. Oncogene 2007;26:2166-76.

10. Petitjean A, Mathe E, Kato S, Ishioka C, Tavtigian SV, Hainaut P, Olivier M. Impact of mutant p53 functional properties on TP53 mutation patterns and tumor phenotype: lessons from recent developments in the IARC TP53 database. Hum Mutat 2007;28:6229 .

11. Guichard C, Amaddeo G, Imbeaud S, Ladeiro Y, Pelletier L, Maad IB, Calderaro J, Bioulac-Sage P, Letexier M, Degos F, Clément B, Balabaud C, Chevet E, Laurent A, Couchy G, Letouzé E, Calvo F, Zucman-Rossi J. Integrated analysis of somatic mutations and focal copy-number changes identifies key genes and pathways in hepatocellular carcinoma. Nat Genet. 2012;44:694-8.

12. Whittaker S, Marais R, Zhu AX. The role of signaling pathways in the development and treatment of hepatocellular carcinoma. Oncogene 2010;29:4989-5005.

13. Huang J, Deng Q, Wang Q, Li KY, Dai JH, Li N, Zhu ZD, Zhou B, Liu XY, Liu RF, Fei QL, Chen H, Cai B, Zhou B, Xiao HS, Qin LX, Han ZG. Exome sequencing of hepatitis B virus-associated hepatocellular carcinoma. Nat Genet. 2012;44:1117-21.

14. Fujimoto A, Totoki Y, Abe T, Boroevich KA, Hosoda F, Nguyen HH, Aoki M, Hosono N, Kubo M, Miya F, Arai Y, Takahashi H, Shirakihara T, Nagasaki M, Shibuya T, Nakano K, Watanabe-Makino K, Tanaka H, Nakamura H, Kusuda J, Ojima H, Shimada K, Okusaka T, Ueno M, Shigekawa Y, Kawakami Y, Arihiro K, Ohdan H, Gotoh $\mathrm{K}$, Ishikawa O, Ariizumi S, Yamamoto M, Yamada T, Chayama K, Kosuge T, Yamaue H, Kamatani N, Miyano S, Nakagama H, Nakamura Y, Tsunoda T, Shibata T, Nakagawa H. Whole-genome sequencing of liver cancers identifies etiological influences on mutation patterns and recurrent mutations in chromatin regulators. Nat Genet 2012;44:760-4.

15. Xie HJ, Bae HJ, Noh JH, Eun JW, Kim JK, Jung KH, Ryu JC, Ahn YM, Kim SY, Lee SH, Yoo NJ, Lee JY, Park WS, Nam SW. Mutational analysis of JAK1 gene in human hepatocellular carcinoma. Neoplasma 2009;56:136-40.

16. Negrini S, Gorgoulis VG, Halazonetis TD. Genomic instability - an evolving hallmark of cancer. Nat Rev Mol Cell Biol 2010;11:220-8.

17. Bunz F, Fauth C, Speicher MR, Dutriaux A, Sedivy JM, Kinzler KW, Vogelstein B, Lengauer C. Targeted inactivation of p53 in human cells does not result in aneuploidy. Cancer Res 2002;62:1129-33.

18. Gorgoulis VG, Vassiliou LV, Karakaidos P, Zacharatos P, Kotsinas A, Liloglou T, Venere M, Ditullio RA Jr, Kastrinakis NG, Levy B, Kletsas D, Yoneta A, Herlyn M, Kittas C, Halazonetis TD. Activation of the DNA damage checkpoint and genomic instability in human precancerous lesions. Nature 2005;434:907-13. 
19. Bartkova J, Horejsí Z, Koed K, Krämer A, Tort F, Zieger K, Guldberg P, Sehested M, Nesland JM, Lukas C, Ørntoft T, Lukas J, Bartek J. DNA damage response as a candidate anti-cancer barrier in early human tumorigenesis. Nature 2005;434:864-70.

20. Wang Y, Hong Y, Li M, Long J, Zhao YP, Zhang JX, Li Q, You H, Tong WM, Jia JD, Huang J. Mutation inactivation of Nijmegen breakage syndrome gene (NBS1) in hepatocellular carcinoma and intrahepatic cholangiocarcinoma. PLoS One 2013;8:e82426.

21. Miki D, Ochi H, Hayes CN, Abe H, Yoshima T, Aikata H, Ikeda K, Kumada H, Toyota J, Morizono T, Tsunoda T, Kubo M, Nakamura Y, Kamatani N, Chayama K. Variation in the DEPDC5 locus is associated with progression to hepatocellular carcinoma in chronic hepatitis C virus carriers. Nat Genet 2011;43:797-800

22. Zhang H, Zhai Y, Hu Z, Wu C, Qian J, Jia W, Ma F, Huang W, Yu L, Yue W, Wang Z, Li P, Zhang Y, Liang R, Wei Z, Cui Y, Xie W, Ca M, Yu X, Yuan Y, Xia X, Zhang X, Yang H, Qiu W, Yang J, Gong F, Chen M, Shen H, Lin D, Zeng YX, He F, Zhou G. Genome-wide association study identifies $1 \mathrm{p} 36.22$ as a new susceptibility locus for hepatocellular carcinoma in chronic hepatitis B virus carriers. Nat Genet 2010;42:755-8.

23. Liang KH, Lin CC, Yeh CT. GALNT14 SNP as a potential predictor of response to combination chemotherapy using 5-FU, mitoxantrone and cisplatin in advanced HCC. Pharmacogenomics 2011;12:106173

24. Yeh CT, Liang KH, Lin CC, Chang ML, Hsu CL, Hung CF. A single nucleotide polymorphism on the GALNT14 gene as an effective predictor of response to chemotherapy in advanced hepatocellular carcinoma. Int J Cancer 2014;134:1214-24.

25. Guo X, Ba Y, Ma X, An J, Shang Y, Huang Q, Yang H, Chen Z, Xing J. A meta-analysis of array-CGH studies implicates antiviral immunity pathways in the development of hepatocellular carcinoma. PLoS One 2011;6:e28404.

26. Tomlinson IP, Lambros MB, Roylance RR. Loss of heterozygosity analysis: practically and conceptually flawed? Genes Chromosomes Cancer 2002;34:349-53.

27. Lau SH, Guan XY. Cytogenetic and molecular genetic alterations in hepatocellular carcinoma. Acta Pharmacol Sin. 2005;26:659-65.

28. Niketeghad F, Decker HJ, Caselmann WH, Lund P, Geissler F, Dienes HP, Schirmacher P. Frequent genomic imbalances suggest commonly altered tumour genes in human hepatocarcinogenesis. Br J Cancer 2001;85:697-704.

29. Rashid A, Wang JS, Qian GS, Lu BX, Hamilton SR, Groopman JD. Genetic alterations in hepatocellular carcinomas: association between loss of chromosome $4 \mathrm{q}$ and $\mathrm{p} 53$ gene mutations. $\mathrm{Br} J$ Cancer 1999;80:59-66.

30. Zondervan PE, Wink J, Alers JC, IJzermans JN, Schalm SW, de Man RA, van Dekken H. Molecular cytogenetic evaluation of virusassociated and non-viral hepatocellular carcinoma: analysis of 26 carcinomas and 12 concurrent dysplasias. J Pathol 2000;192:207-15

31. Laurent-Puig P, Legoix P, Bluteau O, Belghiti J, Franco D, Binot F, Monges G, Thomas G, Bioulac-Sage P, Zucman-Rossi J. Genetic alterations associated with hepatocellular carcinomas define distinct path-ways of hepatocarcinogenesis. Gastroenterology 2001;120:1763-73.

32. Zhang $\mathrm{H}$, Ma H, Wang Q, Chen M, Weng D, Wang H, Zhou J, Li Y, Sun J, Chen Y, Liang X, Zhao J, Pan K, Wang H, Xia J. Analysis of loss of heterozygosity on chromosome $4 \mathrm{q}$ in hepatocellular carcinoma using high-throughput SNP array. Oncol Rep 2010;23:445-55.

33. Peng C, Zhang Z, Wu J, Lv Z, Tang J, Xie H, Zhou L, Zheng S. A critical role for ZDHHC2 in metastasis and recurrence in human hepatocellular carcinoma. Biomed Res Int 2014;2014:832712.

34. Yasui K, Konishi C, Gen Y, Endo M, Dohi O, Tomie A, Kitaichi T, Yamada N, Iwai N, Nishikawa T, Yamaguchi K, Moriguchi M, Sumida Y, Mitsuyoshi H, Tanaka S, Arii S, Itoh Y. EVI1, a target gene for amplification at 3q26, antagonizes transforming growth factor- $\beta$ mediated growth inhibition in hepatocellular carcinoma. Cancer Sci 2015;106:929-37.

35. Yung MK, Lo KW, Yip CW, Chung GT, Tong CY, Cheung PF, Cheung TT, Poon RT, So S, Fan ST, Cheung ST. Copy number gain of granulin-epithelin precursor (GEP) at chromosome 17q21 associates with overexpression in human liver cancer. BMC Cancer 2015;15:264.

36. Slamon D, Eiermann W, Robert N, Pienkowski T, Martin M, Press M, Mackey J, Glaspy J, Chan A, Pawlicki M, Pinter T, Valero V, Liu MC, Sauter G, von Minckwitz G, Visco F, Bee V, Buyse M, Bendahmane B, Tabah-Fisch I, Lindsay MA, Riva A, Crown J; Breast Cancer International Research Group. Adjuvant trastuzumab in HER2positive breast cancer. N Engl J Med 2011;365:1273-83.

37. Bacaksiz A, Sahin FI, Bilezikci B, Yilmaz Z. Determination of HER-2/ Neu status in hepatocellular carcinoma cases. Genet Test 2008;12:211-4.

38. Panvichian R, Tantiwetrueangdet A, Angkathunyakul N, Leelaudomlipi S. TOP2A amplification and overexpression in hepatocellular carcinoma tissues. Biomed Res Int 2015;2015:381602.

39. Giefing M, Zemke N, Brauze D, Kostrzewska-Poczekaj M, Luczak M, Szaumkessel M, Pelinska K, Kiwerska K, Tönnies H, Grenman R, Figlerowicz M, Siebert R, Szyfter K, Jarmuz M. High resolution ArrayCGH and expression profiling identifies PTPRD and PCDH17/ PCH68 as tumor suppressor gene candidates in laryngeal squamous cell carcinoma. Genes Chromosomes Cancer 2011;50:154-66.

40. Nalesnik MA, Tseng G, Ding Y, Xiang GS, Zheng ZL, Yu Y, Marsh JW, Michalopoulos GK, Luo JH. Gene deletions and amplifications in human hepatocellular carcinomas: correlation with hepatocyte growth regulation. Am J Pathol 2012;180:1495-508.

41. Kohno T, Otsuka A, Girard L, Sato M, Iwakawa R, Ogiwara H, Sanchez-Cespedes M, Minna JD, Yokota J. A catalog of genes homozygously deleted in human lung cancer and the candidacy of PTPRD as a tumor suppressor gene. Genes Chromosomes Cancer 2010;49:342-52

42. Acun T, Demir K, Oztas E, Arango D, Yakicier MC. PTPRD is homozygously deleted and epigenetically downregulated in human hepatocellular carcinomas. OMICS 2015;19:220-9. 